\title{
Manajemen Skala Prioritas dalam Aspek Keuangan Rumah Tangga pada Masa Pandemi Covid 19
}

\author{
Anggit Dyah Kusumastuti*, Destina Paningrum \\ Universitas Sahid Surakarta, Indonesia \\ *Coresponding Author: anggit.dyahkusumastuti@usahidsolo.ac.id \\ Dikirim: 26-01-2022; Direvisi: 03-02-2022; Diterima: 04-02-2022
}

\begin{abstract}
Abstrak: Pandemi covid 19 yang terjadi di Indonesia menciptakan ketidakstabilan dan krisis di sektor ekonomi, khususnya sektor rumah tangga. Kurangnya pengetahuan ibu rumah tangga dalam menentukan skala prioritas kebutuhan sehari-hari merupakan salah satu faktor yang menyebabkan kesulitan ekonomi dalam rumah tangga pada saat pandemi covid 19. Kegiatan pengabdian kepada masyarakat dengan tema manajemen skala prioritas dalam aspek keuangan rumah tangga pada masa pandemi covid 19 pada ibu-ibu rumah tangga di lingkungan RT 04 RW 12 Kelurahan Pajang, Laweyan, Surakarta bertujuan untuk meningkatkan pengetahuan dalam pengelolaan keuangan rumah tangga sehingga ibu-ibu rumah tangga dapat membuat suatu perencanaan dan penganggaran keuangan rumah tangga secara optimal. Pengelolaan keuangan rumah tangga merupakan salah satu solusi sehingga penggunaan sumber daya ekonomi terutama dalam hal keuangan dapat direncanakan, dipantau, dievaluasi, dan dikendalikan untuk menjamin stabilitas ekonomi keluarga. Metode yang digunakan dalam kegiatan pengabdian ini adalah dengan melakukan sosialisasi dan diskusi yang berkaitan dengan materi manajeman skala prioritas dalam aspek keuangan rumah tangga pada masa pandemi covid 19. Hasil dari kegiatan ini adalah Ibu-ibu rumah tangga yang hadir dapat menambah pengetahuan dan pemahaman tentang pengelolaan keuangan berdasarkan manajemen keuangan dan prinsip akuntansi.
\end{abstract}

Kata kunci : covid 19; keuangan rumah tangga; skala prioritas

Abstract: The covid 19 pandemic that occured in Indonesia created instability and crisis in the economic sector, especially the household sector. The lack of knowledge of housewives in determining the priority scale for daily needs is one of the factors that cause economic difficulties in household during the covid 19 pandemic. Community service activities with the theme management of priority scale in household financial aspects during the covid 19 pandemic in housewives in RT 04 RW 12 Kelurahan Pajang, Laweyan Surakarta aims to increase knowledge in household financial management so that housewives can make a planning and budgeting optimal. Household financial management is one solution so that the use of economic resources, especially in terms of finances, can be planned, monitored, evaluated and controlled to ensure family economic stability. The method used in this service activity is conduct socialization and discussion related to priority scale management material in household financial aspect during the covid 19 psndemic. The result of this activity is that housewives who attend can increase their knowledge and understanding of management finance based on financial management and accounting principles.

Keywords: covid 19; household; priority scale

\section{PENDAHULUAN}

Pandemi covid 19 yang terjadi di hampir semua negara menimbulkan gejolak perekonomian dan berdampak pada sektor rumah tangga. Masa pandemi menyebabkan banyak kelumpuhan di berbagai bidang terutama di bidang ekonomi. 
Hal ini berdampak pada perusahaan pemberi kerja yang mengalami masa sulit dan harus bertahan di masa pandemi. Sehingga perusahaan akan mengambil tindakan untuk dapat mengatasi masa sulit dengan pengurangan jumlah karyawan dan mengurangi jumlah kompensasi yang diberikan kepada karyawan. Sedangkan keluarga yang bergantung dari penghasilan ini harus tetap bertahan terutama dalam memenuhi kebutuhan hidupnya. Oleh karena pengelolaan keuangan keluarga di masa pandemi harus dilakukan dengan baik. Pengelolaan keuangan adalah sebuah tindakan untuk mencapai tujuan keuangan di masa yang akan datang (Bank Indonesia, 2013). Pengelolaan keuangan adalah teknik mengimbangi gaya hidup manusia seperti gaya hidup konsumtif dengan gaya hidup produktif seperti investasi, menabung maupun bisnis (Senduk, 2004). Pengelolaan keuangan harus memiliki perencanaan keuangan untuk mencapai tujuan jangka pandek maupun jangka panjang. Untuk mencapai tujuan tersebut, maka perlu adanya alokasi dana yang baik sehingga tidak terjebak pada perilaku keinginan yang tak terbatas (Silvy \& Yulianti, 2013). Pengelolaan keuangan meliputi tiga tahapan yaitu pertama perencanaan keuangan, kedua pelaksanaan pengeluaran keuangan, dan ketiga pelaporan keuangan (Wahyudi, 2012).

Permasalahan keuangan merupakan permasalahan umum yang dihadapi sebuah keluarga. Masalah mengatur keuangan seringkali menjadi penyebab utama perselisihan yang terjadi dalam keluarga (Nurmala \& Damayanti, 2005). Namun jika dalam rumah tangga memiliki kendali keuangan yang baik, maka dapat meminimalisir masalah keuangan yang terjadi. Kemampuan mengatur harta atau mengelola keuangan sangat diperlukan dalam lingkup keluarga. Apalagi dalam kondisi ekonomi yang penuh ketidakpastian pada masa pandemi. Anggota keluarga yang berperan mengelola keuangan diharapkan memahami prinsip dasar dalam perencanaan dan pengendalian keuangan keluarga. Pengelolaan keuangan keluarga mengatur pengalokasian penghasilan keluarga. Besar kecilnya penghasilan dalam keluarga, seharusnya dapat dikelola sebaik mungkin agar pengeluaran sesuai dengan pendapatan yang diterima (Ramli \& Apriyanto, 2020).

Menurut survey Otoritas Jasa Keuangan, perencanaan dan pengambilan keputusan di keluarga lebih banyak didominasi oleh kaum perempuan. Manajemen keuangan keluarga sebenarnya merupakan tanggung jawab suami dan istri, namun lebih cenderung merupakan tanggung jawab istri sebagai ibu rumah tangga. Sebagaimana diungkapkan bahwa keterlibatan perempuan dalam sebuah kegiatan itu penting (Sari et.al., 2019). Melihat peran yang begitu besar dari perempuan maka diperlukan pengetahuan dan pemahaman konsep keuangan agar dapat terhindar dari kesalahan dalam pengambilan keputusan keuangan (Kartawinata \& Mubaraq, 2018). Ibu rumah tangga dalam keluarga tidak hanya berperan untuk mengurus semua anggota keluarga serta keperluan rumah tangga,tetapi juga berperan untuk mengelola keuangan keluarga. Ketidakmampuan ibu rumah tangga dalam melakukan perencanaan dan pengelolaan keuangan dapat megakibatkan pengeluaran keluarga yang lebih besar dari jumlah penghasilan yang didapatkan. Adapun langkah dalam pengelolaan keuangan keluarga adalah : 1) Melakukan pencatatan harta yang dimiliki, 2) Melakukan pencatatan semua pemasukan dan pengeluaran, 3) Mengidentifikasi pengeluaran rutin, dan 4) Menyusun rencana pengeluaran.

Setiap individu dalam rumah tangga baik sudah menikah maupun belum pasti pernah merasakan dan menghadapi permasalahan keuangan. Dalam situasi kondisi normal suatu pengelolaan keuangan yang salah bisa menimbulkan banyak masalah 
bagi keluarga, apalagi dalam situasi pandemi covid 19 seperti saat ini. Setiap individu atau keluarga selalu merasa kekurangan uang dikarenakan dalam pengeluaran atau konsumsi belum menerapkan skala prioritas yang membedakan antara kebutuhan dan keinginan. Hal ini terjadi karena keluarga tidak memiliki pengetahuan akuntansi atau tidak memahami manajemen keuangan dalam keluarga. Kurang memadainya pengetahuan tentang perencanaan dan pengaturan keuangan menyebabkan tujuan kesejahteraan dalam keluarga tidak tercapai dengan maksimal (Mulyati \& Hati, 2021). Banyak orang yang mengalami kesulitan dalam mengelola keuangan karena tidak dapat mengontrol keinginan. Orang-orang yang mengalami kesulitan mengelola keuangan keluarga seringkali salah memprioritaskan pengeluarannya (Badriah \& Nurwanda, 2009). Berdasarkan permasalahan tersebut kami berinisiatif melaksanakan kegiatan pengabdian kepada masyarakat dengan tema "Manajemen Skala Prioritas Dalam Aspek Keuangan Rumah Tangga Pada Masa Pandemi Covid 19" yang telah dilaksanakan pada tanggal 28 November 2021 di lingkungan RT 04 RW 12 Kelurahan Pajang, Laweyan, Surakarta.

Berdasarkan uraian pendahuluan dan latar belakang yang telah dijelaskan sebelumnya, maka rumusan masalah dalam kegiatan pengabdian kepada masyarakat ini adalah bagaimana cara mengelola dan merencanakan keuangan rumah tangga selama pandemi covid 19 agar tetap dapat diatur seoptimal mungkin. Sedangkan tujuan dari pelaksanaan kegiatan pengabdian kepada masyarakat ini adalah untuk mengetahui pengelolaan dan perencanaan keuangan rumah tangga selama pandemi covid 19 agar tetap dapat diatur seoptimal mungkin. Sehingga manfaat yang bisa diambil dalam kegiatan pengabdian kepada masyarakat adalah Ibu-ibu rumah tangga yang hadir dapat menambah pengetahuan dan pemahaman tentang pengelolaan keuangan berdasarkan manajemen keuangan dan prinsip akuntansi.

\section{METODE PELAKSANAAN KEGIATAN}

Metode pelaksanaan dalam kegiatan pengabdian kepada masyarakat adalah :

a. Survey pendahuluan. Melakukan komunikasi dengan ibu ketua RW 12 Kelurahan Pajang, Laweyan, Surakarta untuk mendapatkan ijin pelaksanaan kegiatan pengabdian kepada masyarakat.

b. Persiapan pelaksanaan kegiatan

c. Sosialisasi. Melakukan pemaparan tentang manajemen skala prioritas dalam aspek keuangan rumah tangga pada masa covid 19.

\section{IMPLEMENTASI KEGIATAN DAN PEMBAHASAN}

Permasalahan yang dihadapi oleh ibu-ibu rumah tangga lingkungan RT 04 RW 12 Kelurahan Pajang, Laweyan, Surakarta adalah sulitnya mengatur dan mengelola keuangan rumah tangga di masa pandemi covid 19. Hal ini disebabkan karena kebutuhan rumah tangga di masa pandemi yang semakin tidak terbatas jumlahnya sedangkan besarnya nominal penghasilan yang tetap. Oleh karena itu sebagai ibu rumah tangga harus pandai dalam mengelola keuangan rumah tangga agar kebutuhan tetap dapat terpenuhi dengan baik. Dari keadaan diatas, maka kegiatan pengabdian yang dilakukan oleh tim pengabdian prodi Administrasi Bisnis Universitas Sahid Surakarta diharapkan dapat menambah pengetahuan kepada ibu-ibu rumah tangga tentang manajemen skala prioritas dalam aspek keuangan rumah tangga pada masa 
covid 19. Berikut adalah susunan kegiatan yang dilakukan selama waktu kegiatan pengabdian kepada masyarakat berlangsung :

1. Minggu tanggal 21 November 2021 dilaksanakan survey pendahuluan dengan melakukan pertemuan bersama ibu ketua RW 12 untuk meminta izin atas kegiatan pengabdian yang akan dilakukan.

2. Minggu tanggal 28 November 2021 dilaksanakan persiapan kegiatan pengabdian kepada masyarakat dengan judul "Manajemen Skala Prioritas Dalam Aspek Keuangan Rumah Tangga Pada Masa Pandemi Covid 19” di Rumah ibu Djoko Raksono RT 04 RW 12 No. 8 Kelurahan Pajang, Laweyan, Surakarta dengan urutan acara sebagai berikut :

a. Pembukaan kegiatan pengabdian (pukul 10.00 WIB -10.15 WIB)

b. Penyampaian materi pengenalan umum tentang manajemen skala prioritas dalam aspek keuangan rumah tangga pada masa pandemi covid 19 (pukul 10.15 WIB - 10.45 WIB)

c. Sesi diskusi dan tanya jawab dengan ibu-ibu rumah tangga yang hadir dalam kegiatan pengabdian (pukul 10.45 WIB - 11.30 WIB)

d. Penutup

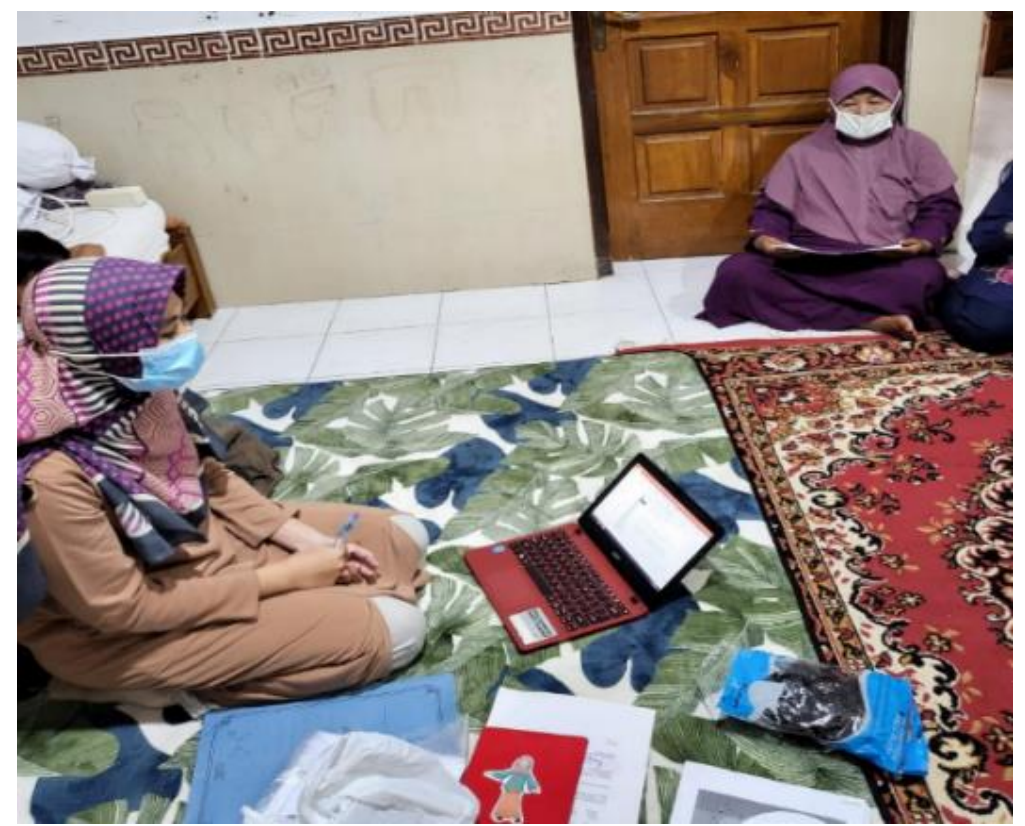

Gambar 1. Penyampaian materi "Manajemen Skala Prioritas Dalam Aspek Keuangan Rumah Tangga Pada Masa Pandemi Covid 19"

Pencatatan dan penganggaran keuangan dalam organisasi merupakan suatu hal yang penting tak terkecuali dalam rumah tangga khususnya di masa pandemi covid 19 . Hal ini dianjurkan untuk dilakukan dalam menjaga finansial keluarga agar tetap stabil dan mampu menopang kebutuhan keluarga. Jika suatu keluarga melaksanakan penganggaran serta pengelolaan keuangan dengan tepat dan benar berdasarkan prinsip akuntansi, maka akan sangat membantu tiap keluarga untuk mengelola keuangan secara maksimal dan efektif dengan harapan agar ekonomi keluarga dapat stabil dan bisa menghadapi kendala-kendala yang terkait dengan keadaan keuangan di masa depan. 


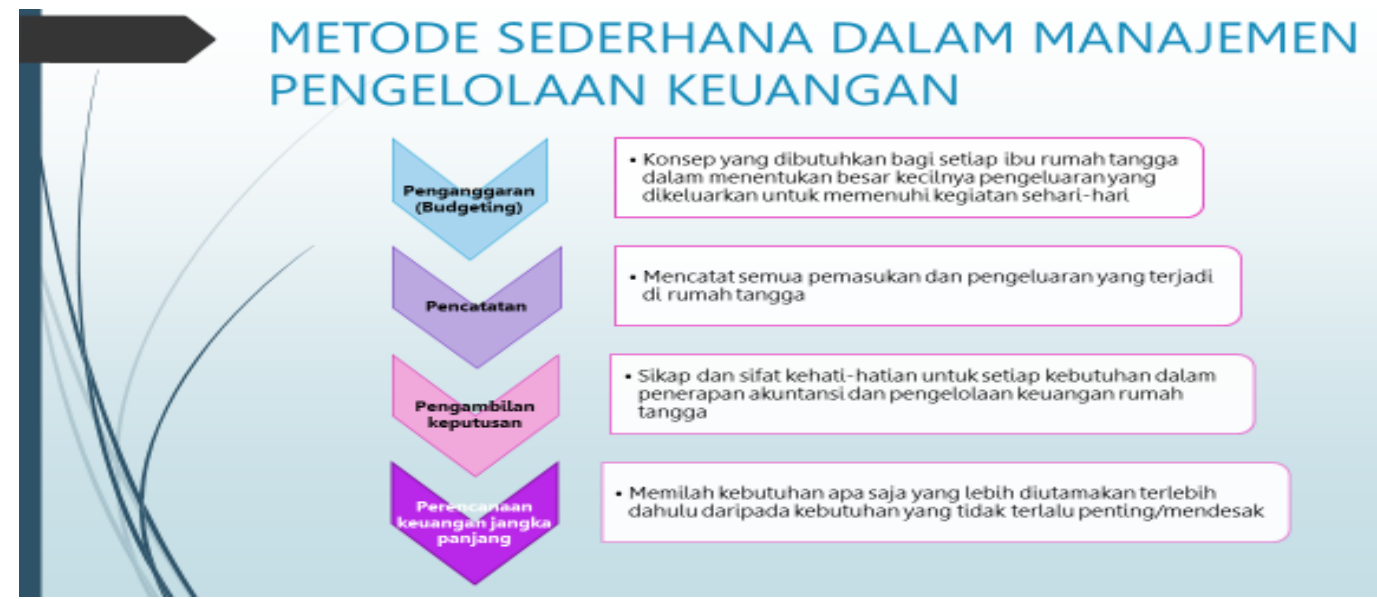

Gambar 2. Metode Sederhana dalam Manajemen Pengelolaan Keuangan

Proses pencatatan keuangan dalam rumah tangga juga sangat diperlukan karena merupakan bagian terpenting dari pengelolaan keuangan rumah tangga. Pencatatan disini merupakan setiap bentuk akan kebutuhan-kebutuhan apa saja yang paling utama dalam rumah tangga. Setiap pencatatan dianjurkan untuk dilakukan dalam buku kas serta dicatat dengan rapi setiap hari, minggu atau bulan. Proses pencatatan ini juga akan membantu dalam menganggarkan cadangan masa depan (deposito) dalam tabungan untuk diperlukan sewaktu-waktu sesuai dengan kebutuhan.

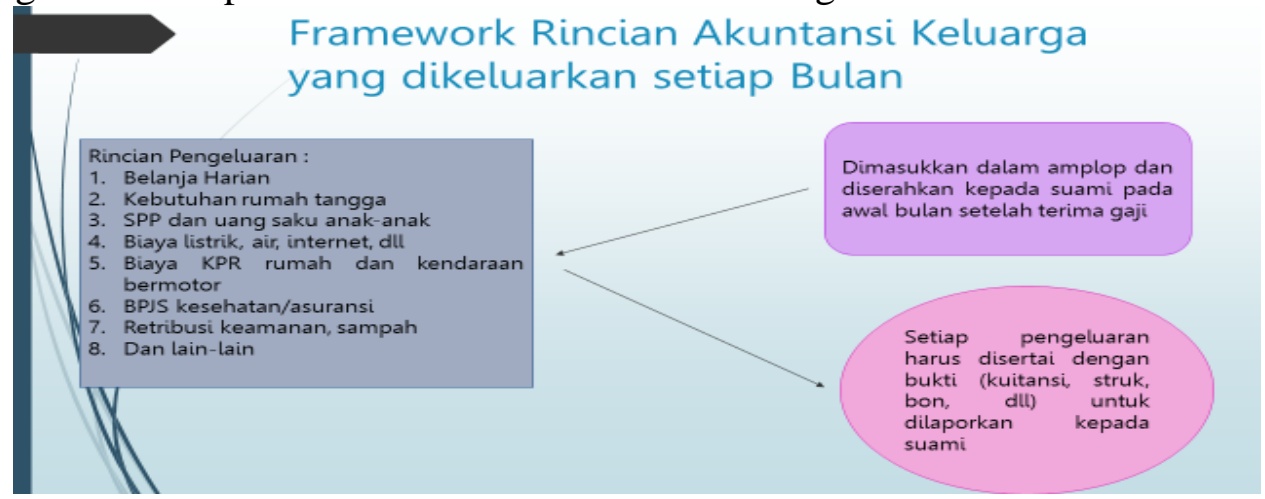

Gambar 3. Pencatatan Rincian Pengeluaran Keluarga Secara Umum Setiap Bulan

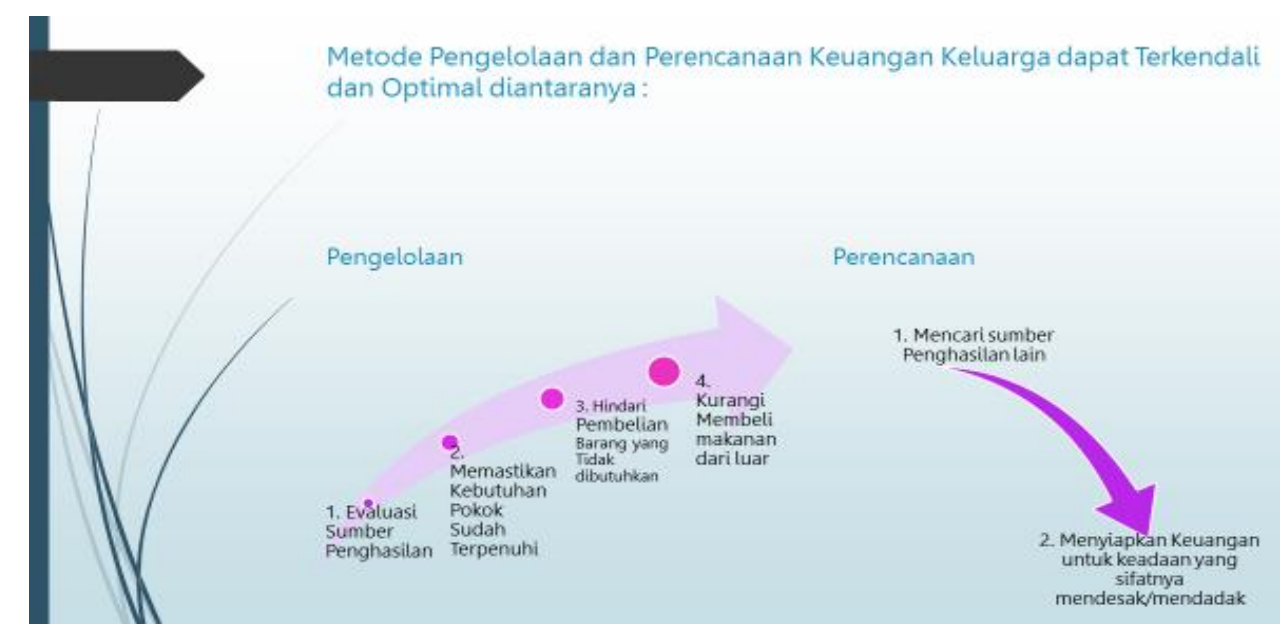

Gambar 4. Metode Pengelolaan dan Perencanaan Keuangan Keluarga dapat Terkendali dan Optimal 
Menentukan skala prioritas dalam hal ini adalah meletakkan sesuatu secara proporsional. Menempatkan sesuatu sesuai pada tempatnya artinya tidak boleh mendahulukan sesuatu yang seharusnya di akhir dan mengakhirkan sesuatu yang seharusnya di awal. Secara garis besar membagi skala prioritas ke dalam beberapa bagian sebagai berikut :

1. Kebutuhan primer adalah kebutuhan utama atau pokok yang harus dipenuhi oleh manusia. Yakni kebutuhan akan sandang, pangan dan papan.

2. Kebutuhan sekunder adalah kebutuhan yang dapat dipenuhi setelah kebutuhan primer atau dengan kata lain kebutuhan sekunder adalah kebutuhan tambahan yang bersifat pelengkap.

3. Kebutuhan tersier adalah kebutuhan yang bersifat hiburan. Kebutuhan ini dapat dicapai setelah kebutuhan primer dan sekunder.

Pembuatan anggaran belanja dalam rumah tangga merupakan hal yang sangat penting dilakukan karena anggaran belanja rumah tangga sebagai perencanaan yang berisi kebutuhan-kebutuhan apa saja yang harus diperoleh. Membuat anggaran belanja juga membuat keluarga dapat mengetahui sisa uang yang tersisa setelah memperoleh semua kebutuhan yang telah dicatat. Dari uang tersisa tersebut dapat dimanfaatkan sebagai investasi di masa depan seperti dimasukkan ke dalam tabungan atau langsung dimanfaatkan sebagai bentuk investasi aktiva tetap.

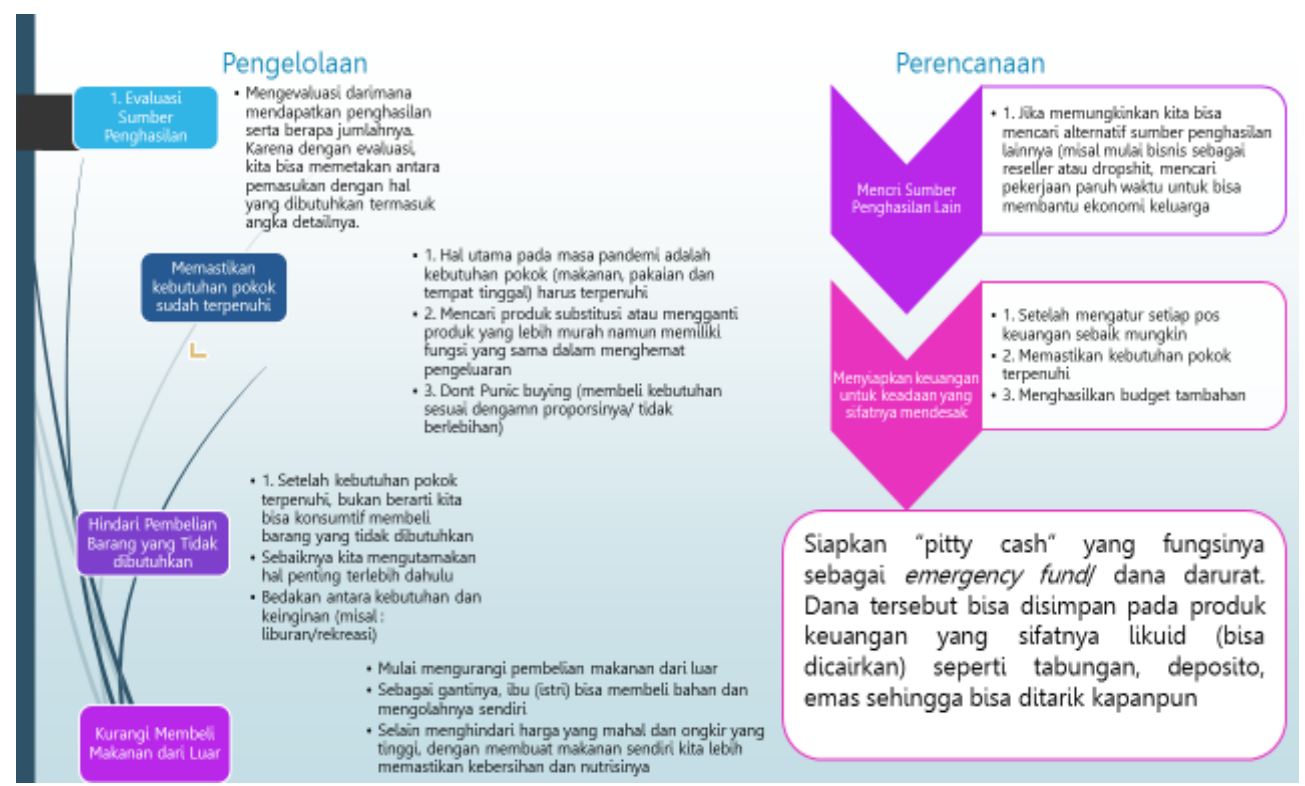

Gambar 5. Strategi Pengelolaan dan Perencanaan Keuangan Rumah Tangga 


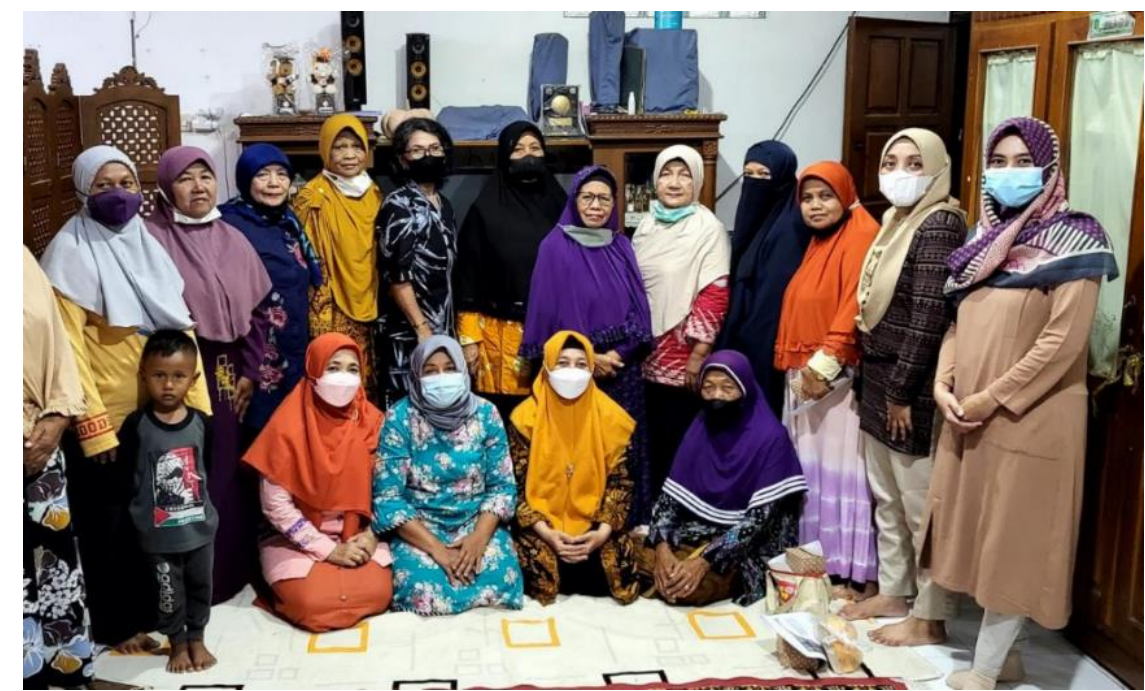

Gambar 6. Foto Bersama dengan Ibu-ibu peserta kegiatan pengabdian kepada masyarakat

\section{KESIMPULAN}

Tim pengabdian prodi Administrasi Bisnis Universitas Sahid Surakarta telah melakukan kegiatan pengabdian kepada masyarakat pada ibu-ibu rumah tangga lingkungan RT 04 RW 12 Kelurahan Pajang, Laweyan, Surakarta dalam menyampaikan materi manajemen skala prioritas dalam aspek keuangan pada masa pandemi covid 19. Kegiatan pengabdian ini telah berjalan dengan lancar dan diikuti oleh peserta ibu-ibu rumah tangga yang memiliki semangat yang tinggi untuk menambah pengetahuan di dalam pengelolaan keuangan berdasarkan manajemen keuangan dan prinsip akuntansi. Manajemen pengelolaan keuangan dalam rumah tangga sangat penting diadakan karena dapat menambah literasi dalam pengelolaan, pencatatan pengeluaran dengan menerapkan skala prioritas dengan membedakan pengeluaran produktif dan pengeluaran konsumtif serta memetakan antara kebutuhan dan keinginan.

\section{DAFTAR PUSTAKA}

Badriah, E. \& Nurwanda, A. (2009). Pelatihan Peranan Ibu Muda Dalam Mengelola Keuangan Rumah Tangga Sebagai Salah Satu Usaha Mengentaskan Kemiskinan. Abdimas Galuh, 1(1), p.8

Bank Indonesia, (2013). Pengelolaan keuangan. Jakarta: Grup Pengembangan Keuangan Inklusif Departemen Pengembangan Akses Keuangan dan UMKM Bank Indonesia

Nurmala \& Damayanti. (2015). Pelatihan Pencatatan dan Manajemen Keuangan Keluarga bagi Kelompok Pengajian/PKK RT 006 Rajabasa Raya. Jurnal Pengabdian pada Masyarakat, pp 96-109.

Mulyati, S. \& Hati, R. P. (2021). Pengaruh Literasi Keuangan dan Sikap terhadap Uang pada Pengelolaan Keuangan Keluarga. Jurnal Ilmiah Akuntansi dan Finansial Indonesia, 4(2), pp. 33-48 
Ramli, M. \& Apriyanto, M. (2020). Manajemen Keuangan Untuk Meningkatkan Perekonomian Keluarga di Masa Pandemi Covid 19. Jurnal BAPPEDA, X(X), $1-8$

Kartawinata, B, R. \& Mubaraq, I. M. (2018). Pengaruh Kompetensi Keuangan Terhadap Literasi Keuangan Bagi Wanita di Makasar. OIKOS Jurnal Kajian Pendidikan Ekonomi dan Ilmu Ekonomi, II, 87-100

Sari, I. D., Septiani, P. E., Suri, U. A., Salamah, H., \& Nuvitalia, D. (2019). Pemberdayaan Perempuan Pesisir Dalam Mewujudkan Kampung Krumi Untuk Meningkatkan Perekonomian Desa Bendar. Dinamisia, hal 106-111

Senduk, S. (2004). Siapa Bilang Jadi Karyawan Nggak Bisa Kaya : Lima Kiat Praktis Mengelola Gaji Agar Bisa Kaya. Jakarta : Elex Media Komputindo

Silvy, M. \& Yulianti, N. (2013). Sikap Pengelola Keuangan dan Perilaku Perencanaan Investasi Keluarga di Surabaya. Journal of Business and Banking, 3(1), pp.5768

Wahyudi, D. (2012). Modul 6 Pengelolaan Keuangan Keluarga. Pusat Pengembangan Pendidikan Nonformal dan Informal Regional I. Kementerian Pendidikan dan Kebudayaan 